\title{
RISK MANAGEMENT TOOL FOR IMPROVING PROJECT FLOWS FOR CONSTRUCTION PROJECTS ON EXISTING BUILDINGS
}

\author{
Zvonko Sigmund \\ Faculty of Civil Engineering, University of Zagreb, $\mathrm{PhD}$ \\ Corresponding author: zsigmund@grad.hr \\ Mladen Radujković \\ Faculty of Civil Engineering, University of Zagreb, $P h D$
}

\begin{abstract}
Old cores of European cities make more than $35 \%$ of the entire building stock in Europe, which and often form the social, financial, and touristic centers of cities. These old buildings require constant investments in terms of renewal and preservation to retain their usefulness. Existing risk management tools do not provide sufficient support when managing these types of projects. Hence, previously developed risk breakdown structures (RBSs) for projects on existing buildings were extended to enable simpler project management and clear visibility of critical risks.

Previous studies focused on RBSs for construction projects in general. Research with respect on real life projects showed that some risk sources posed a greater threat and had more risk triggers than other risk sources. This study identified critical risk sources with respect to existing RBS and conducted a further analysis of these risk sources. The results of the study examined the fully developed RBS for existing building construction projects with further structuring of specific risk sources. Furthermore, the study identified stakeholders and assigned their risk resolution responsibilities.
\end{abstract}

Keywords: Risk breakdown structure; RBS; existing buildings; construction projects; retrofitting; risk management

\section{ALATI ZA UPRAVLJANJE RIZICIMA U PROJEKTIMA OBNOVE POSTOJEĆIH ZGRADA}

Sažetak: Stari centri Europskih gradova čine više od 35\% ukupnog građevnog inventara, a nerijetko predstavljaju socijalno, financijsko, pa i turističko središte gradova. Stare zgrade građevnog inventara zahtijevaju održavanje i obnovu kako bi se održala njihova korisnost. Kako dosadašnji alati za upravljanje rizicima u nisu omogućavali zadovoljavajuće upravljanje rizicima u ovakvom tipu projekata. Razvijena struktura rizika (RBS) koju su autori prethodno predstavili, je dorađena, a kako bi omogućila jednostavnije upravljanje rizicima i ukazala na kritične izvore rizika

Prethodno je objavljen RBS za građevinske projekte na postojećim zgradama. Iskustvo na realnim projektima je pokazalo da neki izvori rizika iz prethodno objavljenog RBS-a predstavljaju veću opasnost po izvršenje projekta i imaju više pokretača od ostalih izvora rizika. Na temelju postojećeg RBS-a kritični izvori rizika su identificirani, a izvršena je i njihova daljnja analiza. Kao rezultat ovog istraživanja u ovom radu predstavljena je u cijelosti razvijena struktura rizika za građevinske projekte na postojećim zgradama, a u kojoj su detaljnije strukturirani kritični izvori rizika. Nadalje, identificirani su bitni sudionici, te su ovima pripisani izvori rizika za koje su odgovorni.

Ključne riječi: razvijena struktura rizika; postojeće zgrade; građevinski projekti; obnova; upravljanje rizicima 


\section{INTRODUCTION}

\subsection{On the resilience in seismic hazard management}

The concept of hazard resilience is now widely adopted across academic and policy debates as a way of reducing society's vulnerability to threats posed by natural and human induced hazards [1]. The term "resilience," originates from a Latin word that means "jump back" or "bounce back" [2]. In the context of disasters, resilience is explained as the ability of individuals to recover to a normally functioning society within the shortest possible time with minimal or no assistance. The term "bounce back" could imply that the vulnerability is also returned. Hence, it is necessary to strengthen existing structures and institutions to resist further possible disasters [2]. Thus, resilience can be viewed as "the intrinsic capacity of a system, community, or society predisposed to a shock or stress to recover, 'bounce forward', and adapt in order to survive by changing its non-essential attributes and rebuilding itself' [2]. In summary, resilience can be defined as "the ability of a system, community or society exposed to hazards to resist, absorb, accommodate to and recover from the effects of a hazard in a timely and efficient manner, including the preservation and restoration of its essential basic structures and functions" as defined by UNISDR [3].

Generally, increasing the resilience of a society against all kinds of disasters has become a major concern in developed and developing countries. Recently, a trend of increasing the resilience of the critical infrastructure and/or the entire built environment (if excessive vulnerability is expected) for preventive protection measures to protect people and the built environment has been observed, as reported by the World Bank Group [4].

Research by Sigmund [5] indicated that Croatia urgently requires the preventive management of seismic hazards presented by old buildings with questionable seismic resistance to prevent disasters from earthquakes and to increase the resilience of the society. This study focused on the idea that the best was to preventively manage seismic hazard, is to govern the resilience increasing process using risk management procedures. The study examined the development of risk management tools for the successful guidance of existing building construction projects.

\subsection{On the risk management in construction}

The construction industry when compared to other industries is exposed to more types of risks due to unique boundary conditions including long production periods, complicated processes, environmental influences, financial intensity, and dynamic organization structures $[6,7]$. Risk analysis is important since both time and cost overruns are unavoidably a part of almost any construction project. However, most previous researches focused on construction projects as projects in general. Additionally, they examined the impacts of risks on various aspects such as costs [8], time [9], quality, and safety [10]. Other researchers investigated risks in different project phases including the conceptual phase [11], design phase [12], and construction phase [13] or even on construction projects in general [14]. These studies suggested that different sets of risks and risk sources are faced by construction projects in different phases from different perspectives. Furthermore, there are differences in risks and risk sources in every construction phase and in every different construction project type. Nevertheless, there is very limited research on retrofitting and renewal or strengthening of existing buildings.

As indicated by Sigmund et al. [15], construction projects on existing buildings face different risk types, and therefore cannot be successfully governed by existing risk management tools. The Project Management Institute (PMI) recognizes that all risk management processes include the following six stages of risk management [16]:

- risk management planning

- risk identification

- qualitative risk analysis

- quantitative risk analysis

- risk response planning

- risk monitoring and control

It is optimal to implement the last three stages of risk management, namely, quantitative risk analysis, risk response planning, and monitoring and control, after understanding the specific project in question and its boundary conditions. However, certain project types have a tendency to be specifically prone to some types of risks or risk 
sources. Hence, in the presented research these risks and their risk sources were be successfully identified based on experiences on projects of a similar type. This study suggests methods to enable a continuous process of strengthening works on existing buildings, which partially enable systematical seismic hazard mitigation. In this study an additional step of identifying project specific risk sources is discussed, thereby extending the risk breakdown structure (RBS) for construction projects on existing buildings proposed in a previous study. Additionally, the study examines an allocation of parties that are responsible for the resolution to simplify the project managers' task of risk analysis and response planning.

\section{PAST RISK RESEARCH AND RISK CLASSIFICATION}

Identifying risks is the first task of the risk manager by which risk components are determined which may adversely affect the project objectives [17]. The identified risks are classified according to different interconnections such as the effect on time, cost, and quality, and their interdependencies are marked [14, 18, 19].

The third step of the risk management process includes qualitative risk analysis, which according to the PMI [16], is the most important step of the risk management process. Qualitative risk analysis enables the analyst to understand the project and its potential problems. Qualitative risk analysis also includes risk identification and classification with all the elements that act as risk triggers [14]. The most used risk categorization type is categorization according to risk sources. This approach was accepted by the PMI [16] and Standards Australia [20]. The existing risk management tools are not particularly helpful in managing projects that involve strengthening and retrofitting or renewal of existing buildings. Therefore, this study examined a new viewpoint that combined structural engineering methods for existing buildings with known risk management tools.

As is indicated by Sigmund et al. [15], existing RBSs showed weaknesses when managing construction works on strengthening and retrofitting or renewal of existing buildings. Thus, a new RBS for construction projects involving existing buildings was developed [Table 1] by Sigmund et al. [15]. Table 1 lists the risks that are specifically relevant for construction works on existing buildings including risks involved in works in the planning and design phase to works in the execution phase. In the table, the risks are classified according to their risk sources.

Table 1 Risk categorization for construction projects on existing buildings [15]

\begin{tabular}{|c|c|c|c|c|c|}
\hline \multicolumn{6}{|c|}{ External risks } \\
\hline Legal risks & Political risks & Economic risks & Social risks & Natural risks & Technical risks \\
\hline $\begin{array}{l}\text { Ownership } \\
\text { Laws; } \\
\text { Regulations and } \\
\text { standards; } \\
\text { Work } \\
\text { construction } \\
\text { approvals }\end{array}$ & $\begin{array}{l}\text { Government } \\
\text { shifts; } \\
\text { Political elections; } \\
\text { Conventions; }\end{array}$ & $\begin{array}{l}\text { Monetary } \\
\text { politics; } \\
\text { Inflations; } \\
\text { Financing type } \\
\text { changes; }\end{array}$ & $\begin{array}{l}\text { Strikes; } \\
\text { Ecology; } \\
\text { Culture; } \\
\text { Seasonal working }\end{array}$ & $\begin{array}{l}\text { Earthquakes; } \\
\text { Floods; } \\
\text { Fires; } \\
\text { Extreme } \\
\text { temperatures }\end{array}$ & $\begin{array}{l}\text { Historic design } \\
\text { documentation; } \\
\text { Not evidenced } \\
\text { changes; Past } \\
\text { problems register; } \\
\text { Ground-building; } \\
\text { Building-building } \\
\text { interaction }\end{array}$ \\
\hline \multicolumn{6}{|c|}{ Project risks } \\
\hline $\begin{array}{l}\text { Management } \\
\text { risks }\end{array}$ & $\begin{array}{l}\text { Design } \\
\text { documentation }\end{array}$ & Human factor & $\begin{array}{l}\text { Delivery and } \\
\text { logistics }\end{array}$ & $\begin{array}{l}\text { Contractual } \\
\text { risks }\end{array}$ & $\begin{array}{l}\text { Project } \\
\text { realization risks }\end{array}$ \\
\hline $\begin{array}{l}\text { Non-realistic } \\
\text { goals; } \\
\text { Bad control; } \\
\text { Arrangements; } \\
\text { Organization }\end{array}$ & $\begin{array}{l}\text { Insufficient } \\
\text { investigation; } \\
\text { Expert } \\
\text { estimations; } \\
\text { Bad design } \\
\text { documentation }\end{array}$ & $\begin{array}{l}\text { Users; } \\
\text { Omissions; } \\
\text { Workers; } \\
\text { Motivation; }\end{array}$ & $\begin{array}{l}\text { Insufficient } \\
\text { materials; } \\
\text { Qualified } \\
\text { workers' } \\
\text { availability; } \\
\text { Not } \\
\text { approachable } \\
\text { areas }\end{array}$ & $\begin{array}{l}\text { Contract type; } \\
\text { Prices; } \\
\text { Time; } \\
\text { Chain of control }\end{array}$ & $\begin{array}{l}\text { Feasibility; } \\
\text { Expertise and } \\
\text { experience of } \\
\text { realization } \\
\text { group; } \\
\text { Users-Heritage } \\
\text { protection } \\
\text { needs }\end{array}$ \\
\hline
\end{tabular}




\section{RESEARCH}

\subsection{The motivation}

The experience on these types of construction works involving the strengthening and retrofitting or renewal of existing buildings showed that some risk sources had the ability to considerably impede project development or to stop it completely. Problems like unresolved ownership or changes in projects requested by ministry of culture could suddenly halt the entire project flow when integrating the partial sub-processes as defined by the interdisciplinary project elements of systematic hazard risk mitigation. An originally, "controlled" project could be stopped based on legal or even suddenly shifting feasibility problems. Even though these risks were considered within the previously existing RBS, some risks appeared to have a critical impact on projects involving existing buildings. These risks were not previously anticipated in this form. This suggested that a more in-depth study of the risk sources was needed. Thus, this study further extended the previously presented RBS (shown in the table 1). This study explored the occurrence of critical risks, which had a greater impact on project development, and developed a newly evolved RBS for construction projects on existing buildings with more structured risk sources. This enables a continuous project flow including development, planning, design, and execution of strengthening works on existing buildings to partially facilitate systematical seismic hazard risk mitigation.

\subsection{The research}

The likelihood of the occurrence of a specific risk was analyzed to perform quantitative risk assessment. Furthermore, the risk impact on a project's objectives was assessed taking into account its potentially positive and negative effects that result from threats. As suggested by the PMI [16], probabilities and impacts were specifically tailored to construction projects on existing buildings. Expert opinions were used to assess risk sources and risk occurrence probability.

The data acquisition with respect to the risk sources and risks analysis involved 10 experts chosen based on their long term involvement on cultural heritage preservation and strengthening projects (at least 7 years of experience and at least 3 projects of similar kind). The experts were presented with a questionnaire where each risk source was to be graded according to the risk occurrence probability and possible impact.

Risk occurrence probabilities were graded as "low", "medium", and "high". Conversely, risk impacts were graded as "very high", "high", "medium" and "low". A list of critical risk sources was identified using the database of collected expert opinions. The declared critical risk sources included the risk sources evaluated by a majority of the experts as having a medium or high occurrence probability and a high or very high risk impact. The identification of critical risk sources provided inputs for the further development of already existing RBS for construction projects on existing buildings. These critical risk sources were further developed and used such that they could be integrated into project preparation processes.

With respect to each risk impact grade and risk occurrence probability, this study further defined the grades. Each risk source from the already existing RBS [Table 1] was evaluated by the 10 experts by grading each risk source on its occurrence probability and risk impact. Experts opinions were collected by using a form as shown in figure 1 to obtain the risk source and occurrence probability.

The definition of risk impact as defined for the expert opinion assessment included the following

- Very high - the occurrence of this risk could completely stop the project flow if the risk outcome was negative to the project or if it could not be resolved in a reasonable period of time. In this, a reasonable period of time is defined as the time within which other project processes did not have to stop while waiting for the resolution of the risk outcome in question.

- High - the risk impact was rated as high if the outcome of the risk could slow the project flow intensively or switch the project feasibility from feasible to not feasible.

- Medium - the occurrence of risk could impact the cost or time but could not impact project feasibility or/and prolong the project duration for a period exceeding 2 months.

- Low - the occurrence of risk did not include the above-mentioned outcomes.

The definition of occurrence probability as defined for expert opinion assessment included the following: 
Risk management tool for improving project flows for construction projects on existing buildings

- High - the risk occurrence probability could be rated as high if there was a possibility that this risk source occurred in at least 7 out of 10 project cases.

- Medium - the risk occurrence probability could be rated as medium if there was a possibility that this risk source occurred in at least 3 out of 10 project cases.

- Low - the risk occurrence probability could be rated as low if there was a possibility that this risk source occurred in less than 3 out of 10 project cases.

In the following form, mark with " $\mathrm{X}$ " the field that best fits your opinion:

\begin{tabular}{|c|c|c|c|c|c|c|c|c|}
\hline & & \multicolumn{4}{|c|}{ Impact } & \multicolumn{3}{|c|}{ Occurrence } \\
\hline & & $\begin{array}{l}\text { Very } \\
\text { high }\end{array}$ & High & Medium & Low & High & Medium & Low \\
\hline \multirow[t]{4}{*}{ Legal } & ownership & & & & & & & \\
\hline & laws & & & & & & & \\
\hline & standards & & & & & & & \\
\hline & $\begin{array}{l}\text { work \& construction } \\
\text { approvals }\end{array}$ & & & & & & & \\
\hline \multirow[t]{3}{*}{ Political } & government shifts & & & & & & & \\
\hline & political elecions & & & & & & & \\
\hline & conventions & & & & & & & \\
\hline \multirow[t]{2}{*}{ Economic } & monetary politics & & & & & & & \\
\hline & financing type changes & & & & & & & \\
\hline
\end{tabular}

Figure 1 Example of the risk source quantification form used for risk impact and occurrence probability assessment according to expert opinion

Risk sources that received a "high" occurrence probability grade and "very high" and "high" risk impact grade were declared as critical risk sources. These risk sources were further developed by using a brainstorming session. Four experts participated in the brainstorming session to identify further possible risks that were integrated in the already existing RBS.

\section{RESEARCH RESULTS}

The results of the study on the RBS for construction projects on existing buildings identified the following risk sources as critical:

- Ownership risks - As expected, older and other existing buildings changed their owners over time. It was not rare for the buildings to have more than one owner, and this could be a legal issue. Risk sources that are closely associated with building ownership include multiple and not unified owners, and unresolved or unclear ownership problems, wherein users could pretend to be owners. These risk sources could completely halt a construction project as only the owner or a unified owner's council could make investment decisions. The resolution of these problems could take a long period of time.

- Laws, regulations, and standards risks - The preparation of projects on existing buildings could take a long time, and standards and/or laws could change during this period. The project constraint conditions could be completely changed, as according to Croatian law, the protection status of a building that is not of special interest in heritage protection can be changed even after starting the permit acquisition process. This type of risk has a medium probability of occurrence but a high-risk impact as it affects project feasibility.

- Government shifts and elections risks - Projects that are considered as heritage protection or disaster prevention programs are often supported, financed, or started by governments. Therefore, government shifts and elections can have a high impact on these kinds of projects. Additionally, projects dependent 
on government interests, which are not a part of law defined processes, are prone to these risks and can be temporarily or completely stopped by factors such as changes in the government and elections.

- Historic design documentation risks - As per observations and records, although many historic buildings were built based on designs, but their designs were changed during the construction phase, yet introduced according to the local conditions and user inputs. These project changes were approved by experts, but were not documented in the design documentation. Conversely, other buildings had no design documentation and were built based on the experience of a master builder, or the documentation for the buildings was lost over the years. Construction projects in the past had a lower execution quality control, and additionally, the material quality varied from case to case.

- Past problems register risks - Often a register for past problems does not exist. Furthermore, the register could contain misleading information even if it does exist. Further investigation is advised in order to minimize the possible risk impact.

- Expert estimations and Structural condition risks - Historical buildings have a number of unknown variables wherein missing information can be gained either by conducting investigations or expert estimations. Investigations can be costly and may not provide reliable information. On the other hand, expert estimations are a simple way to fill the gap needed to conduct new design calculations. However, these evaluations are often unreliable and a huge risk source. It is extremely important for building interventions to be compatible with the existing structural elements, and thus this element is always present as a risk source due to unknowns in the structure.

- Investor and Owner risks - Work permissions (by user/investor), special and additional requests and finally user/investor induced changes constitute user and investor risk sources. They can slow the project progression and influence project feasibility if not managed properly.

- User-heritage protection risks - Heritage protection officials must approve every intervention in the context of historical buildings, and this can partially or completely restrict the intended interventions. These restrictions can further cause delays in the project flow or influence the project feasibility, thereby causing a complete halt of the project.

- Project feasibility- This risk source was rated as a high impact risk source by a majority of the experts. The previously mentioned risk sources can influence the feasibility of the project. In contrast, a project considered as infeasible by an investor, can cause the project to stop. 
Figure 2 Risk breakdown structure. Critical risk sources are structured to the fourth level as opposed to the already existing RBS developed to the third level (hatched fields are considered as noncritical risks and risk sources)

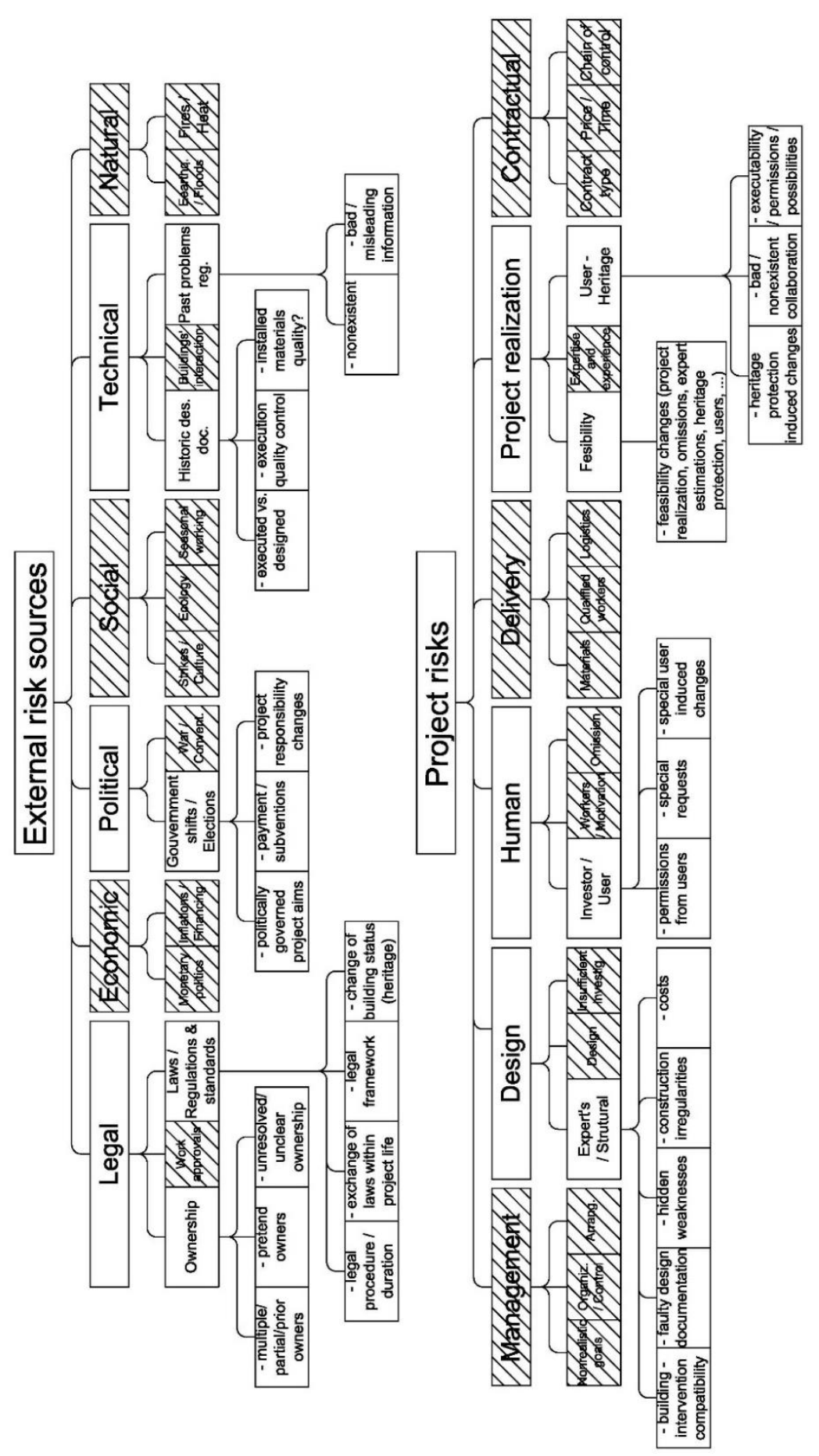

As seen in Figure 2, certain risk sources are now considered as a single source (for example, expert estimations and structural condition risk sources) when compared to the original RBS [Table 1]. This is a result of the undertaken research, as these risk sources tend to have a similar importance to the project and tend to be caused by the same risks. 
The study findings indicated that "ownership," "laws, regulation, and standards", "investor/owner," and "feasibility" risks were identified as significantly critical factors. These risks could completely stop the project. For example, if ownership of the building was not clear or resolved, then no construction work could be undertaken until this problem was resolved.

\subsection{Risk responsibility assignment}

Figure 3 Responsible parties for each critical risk source

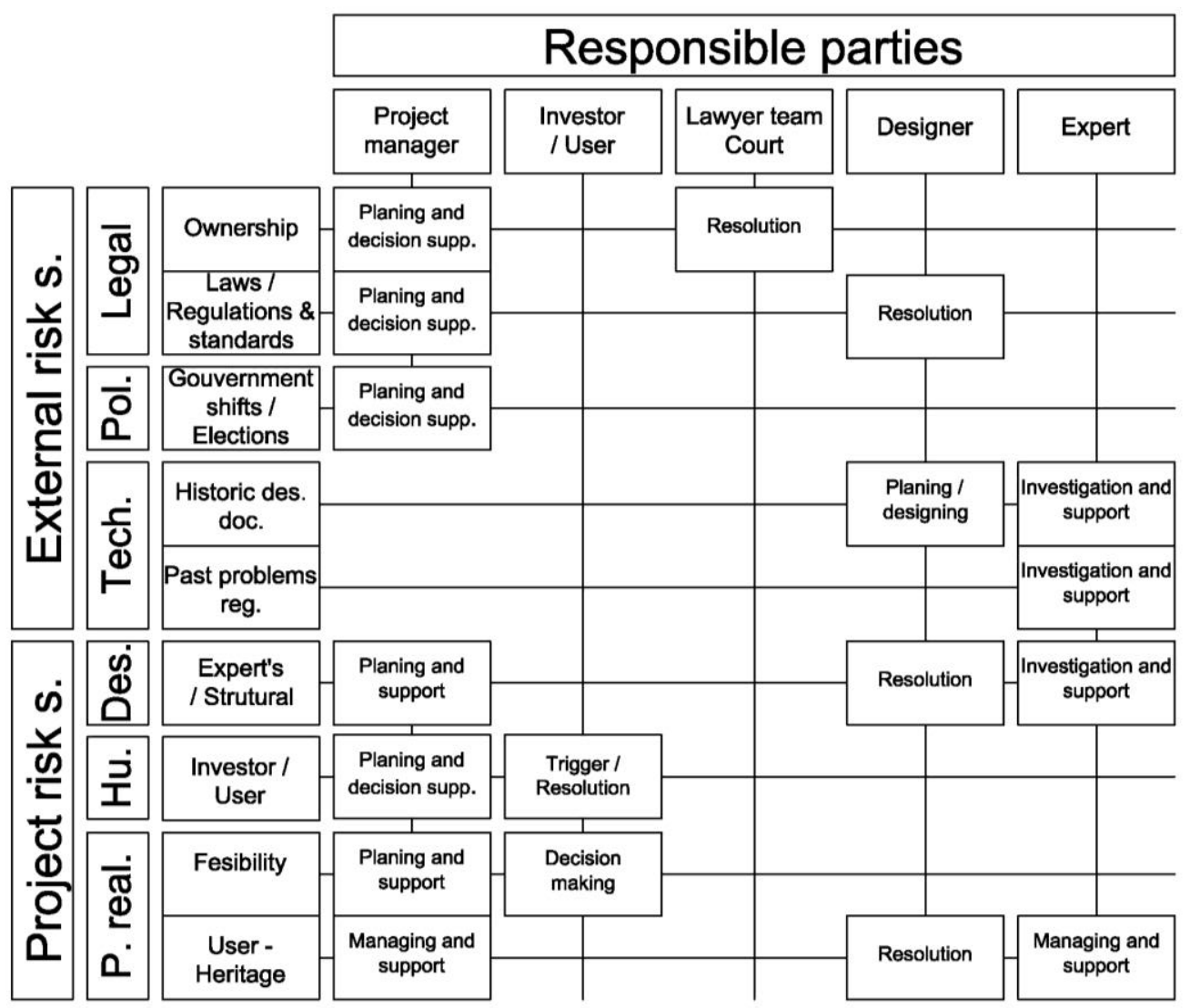

The final aim of the study included ensuring a continuous project flow for systematical seismic hazard mitigation for existing buildings. This necessitates an additional investigation oriented toward the identification of responsible parties involved in the project by the resolution of potential risks.

Most risk sources are caused by parties involved in the project. Nevertheless, in case of risk occurrence, a project party that is not responsible for the response can typically resolve the risk response in most cases. Hence, all stakeholders had to be identified to identify the parties responsible for risk resolution.

The identification of the interested and project involved parties was partially aided by regulations prescribing the involved parties. Additionally, the list was supplemented by brainstorming sessions consisting of experts in the field. In the brainstorming session in which project parties were identified, the risk responsibilities were also assigned for critical risk sources.

The study results presented influenced the formation of a systematic seismic hazard mitigation process. It was also necessary to check the ownership, heritage protection status, and the existence and correctness of the design documentation at the beginning of the process to decrease the possibility of long project halts due to missing or incorrect documentation.

Owners and building users were identified as potentially constituting risks to the project flow. Based on the research results, their influence on the project was limited as they did not have a decision-making role or could not contribute to the risk resolution. It is suggested that building users and/or owners are enabled to request project 
changes only until the start of the design process. Changes requested after the start of the process could be undertaken only if approved by the investor and requested in a written format. This ensured that important parties were included in the project but were not given the ability to influence the project flow and adversely affect the project outcome.

Other risks such as laws, regulations, and standards; government shifts and elections; expert estimations and structural conditions; investor and owner; user-heritage protection; and feasibility risks could not be avoided purely by shaping the project flow differently. Therefore, the project manager is advised to be aware of the possibility of occurrence of these risks. An analysis that uses the results of this study could significantly shorten the long time involved in analyzing heritage protection feasibility and conductibility as major risks can be either avoided or taken into account at the beginning of the planning process. The identification of these critical risks in the planning phase of the hazard mitigation process provided sufficient time to resolve the identified issues before the commencement of the design or execution phase.

\section{CONCLUSION}

This study explored a new and barely researched area of structural engineering by combining projects on existing buildings and existing risk management tools.

The study findings identified critical risk sources from an already existing RBS. In order to identify the critical risk sources, expert opinions were collected, and the following risks were identified as critical based on the expert responses:

- Ownership risks

- Laws, regulations and standards risks

- Government shifts and elections risks

- Historic design documentation risks

- Past problems register risks

- Expert estimations and Structural condition risk sources

- Investor and Owner risk sources

- User-heritage protection risk sources

- Feasibility risk sources

The identified critical risk sources were further analyzed and developed to the fourth level. This enabled a clearer insight of possible risk occurrences. Furthermore, responsible parties for dispute resolution were identified, and responsibilities were assigned based on expert opinions.

The continuity of the project flow of strengthening works on existing buildings can be increased based on the results of this study. The main contribution of this study includes the identification of critical risk sources, which can cause sudden project halts, major project slowdowns, or switches from feasible to infeasible project undertakings. Identification of these risks based on the risk sources presented in this study at the right point of time in the project allows the impact of these risks to be mitigated or even avoided. Therefore, it is important to check the ownership status, heritage protection status, and existence and correctness of the design documentation at the planning phase of the project, and to limit owners and building users in their ability to influence the project flow.

\section{References}

[1] Haigh, R.; Amaratunga, D. 2010: An integrative review of the built environment discipline's role in the development of society's resilience to disasters. International Journal of Disaster Resilience in the Built Environment, 1(1), pp. 11-24. http://dx.doi.org/10.1108/17595901011026454

[2] Manyena, B. et al. 2011: Disaster resilience: a bounce back or bounce forward ability? Local Environment, 16(5), pp. 417-424. http://dx.doi.org/10.1080/13549839.2011.583049

[3] UNISDR. Terminology. United Nations International Strategy for Disaster Reduction 2007 [cited 2016 13.06.2016]; Available from: https://www.unisdr.org/we/inform/terminology.

[4] Gvt. of Mexico and World Bank Group. 2012: Improving the assessment of disaster risks to strengthen financial Resilience. 2012. 296. 
Risk management tool for improving project flows for construction projects on existing buildings

[5] Sigmund, Z. 2014: Public buildings seismic vulnerability risk mitigation management model, Faculty of civil Engineering, University of Zagreb: Zagreb, Croatia. p. 349.

[6] Akintoye, A.S.; MacLeod, M.J. 1997: Risk analysis and management in construction, International Journal of Project Management, 15(1), pp. 31-38. http://dx.doi.org/10.1016/S0263-7863(96)00035-X

[7] Smith, N.J. 2003: Appraisal, risk and uncertainty (Construction management series). 11/2003, London: Thomas Telford Ltd. 304.

[8] Chen, H. et al. 2004: Cost risk management in West Rail project of Hong Kong. AACE International Transactions, pp. IN91 - IN95.

[9] Shen, L.Y. 1997: Project risk management in Hong Kong. International Journal of Project Management, 15(2), pp. 101-105. http://dx.doi.org/10.1016/S0263-7863(96)00045-2

[10] Tam, C.M.; Zeng, S.X.; Deng, Z.M. 2004: Identifying elements of poor construction safety management in China. Safety Science, 42(7), pp. 569-586. http://dx.doi.org/10.1016/i.ssci.2003.09.001

[11] Uher, T.E.; Toakley, A.R. 1999: Risk management in the conceptual phase of a project. International Journal of Project Management, 17(3), pp. 161-169. http://dx.doi.org/10.1016/S0263-7863(98)00024-6

[12] Chapman, R.J. 2001: The controlling influences on effective risk identification and assessment for construction design management. International Journal of Project Management, 19(3), pp. 147-160. http://dx.doi.org/10.1016/S0263-7863(99)00070-8

[13] Abdou, O. 1996: Managing construction risks. Journal of Architectural Engineering, 2(1), pp. 3-10. http://dx.doi.org/10.1061/(ASCE)1076-0431(1996)2:1(3)

[14] Radujković, M. 1997: Upravljanje rizikom kod građevinskih projekata. Građevinar, 5(49), pp. 9.

[15] Sigmund, Z.; Radujković, M. 2014: Risk breakdown structure for construction projects on existing buildings. Procedia-Social and Behavioral Sciences, 119, pp. 894-901. http://dx.doi.org/10.1016/j.sbspro.2014.03.100

[16] Project Management Institute 2000: Project management body of knowledge. Project Management Institute: Four Campus Boulevard, Newtown Square, PA 19073-3299 USA.

[17] KarimiAzari, A. et al. 2011: Risk assessment model selection in construction industry. Expert Systems with Applications, 38(8), pp. 9105-9111. http://dx.doi.org/10.1016/j.eswa.2010.12.110

[18] Edwards, P.J.; Bowen, P.A. 1998: Risk and risk management in construction: a review and future directions for research. Engineering, Construction and Architectural Management, 5(4), pp. 339-349. http://dx.doi.org/10.1108/eb021087

[19] Chapman, C.B. 1979: Large engineering project risk analysis. Engineering Management, IEEE Transactions on, 3, pp. 78-86. http://dx.doi.org/10.1109/TEM.1979.6447349

[20] Standards Australia 1999: Risk management. Standards Australia International Ltd: Sydney, Australia. 